\title{
Intraoperative 3D imaging in intraarticular tibial plateau fractures - Does it help to improve the patients' outcomes?
}

\author{
F. Souleiman ${ }^{*}$ (D, R. Henkelmann ${ }^{\dagger}$, J. Theopold, J. Fakler, U. Spiegl ${ }^{\dagger}$ and P. Hepp ${ }^{\dagger}$
}

\begin{abstract}
Background: In tibial plateau fractures (TPF) the restoration of an anatomical joint surface as well as an exact subchondral screw position for postoperative stability is crucial for the outcome.

The aim of this study was to determine whether the additional use of an intraoperative 3D imaging intensifier (3D) might help to improve the outcome of complex TPF.

Methods: We performed a retrospective case-control study of a level 1 trauma center. Patients with AO/OTA 41 B3 and C-TPF operated on using a 3D imaging intensifier between November 2015 and December 2018 (3D group) were included. The outcomes of this patients were compared to patients operated without 3D imaging between January 2005 to December 2014 (2D group). The comparison of the groups was performed by matched pair analysis. The functional outcome of both groups was measured by KOOS and Lysholm Score after a follow-up period of at least 12 months. Operation time, infections and postoperative revisions were registered.

Results: In total, 18 patients were included in the 3D group (mean age: $51.0 \pm 16.4$ years; 12 females) and an equal number of matching partners from the 2D group (mean age: $50.3 \pm 15.2$ years; 11 females) were found ( $p=0.82 ; p=0.79$ ). We found 9x B3, 2x C1, 1 $\times C 2,6 \times C 3$ fractures according to AO/OTA for each group ( $p=1.00)$ with comparable ASA score $(p=0.27)$. The mean operation time was $127.9 \pm 45.9 \mathrm{~min}$ and $116.1 \pm 45.7 \mathrm{~min}$ for the $3 \mathrm{D}$ and $2 \mathrm{D}$ group $(\mathrm{p}=0.28)$. The mean follow-up time was $20.9 \pm 10.7$ months for the $3 \mathrm{D}$ and $55.5 \pm 34.7$ months for the $2 \mathrm{D}$ group $(\mathrm{p}<0.001)$. For the 3D group a mean Lysholm overall score of $67.4 \pm 26.8$ and KOOS overall score of $72.6 \pm 23.5$ could be assessed. In contrast, a mean Lysholm overall score of $62.0 \pm 21.4$ and KOOS overall score of $65.8 \pm 21.6$ could be measured in the $2 \mathrm{D}$ group $(p=0.39 ; p=0.31)$. Thereby, functional outcome of the 3D group showed a significant higher KOOS Sport/Rec sub score of $54.7 \pm 35.0$ in comparison to the $2 \mathrm{D}$ group with $26.7 \pm 31.6(p=0.01)$. Postoperative revisions had to be performed in $27.8 \%$ of cases in both groups $(p=1.00)$. Due to the 3D imaging an intraoperative revision was performed in $33.3 \%(6 / 18)$.
\end{abstract}

Conclusion: In our study we could show that re-reduction of the fracture or implant re-positioning were performed in relevant numbers based on the 3D imaging. This was associated with a midterm clinical benefit in regard to better KOOS Sport/Rec scores.

(Continued on next page)

\footnotetext{
* Correspondence: firas.souleiman@medizin.uni-leipzig.de

${ }^{\dagger}$ Firas Souleiman and Ralf Henkelmann contributed equally to this article.

${ }^{\dagger}$ Pierre Hepp and Ulrich Spiegl are equally contributing senior authors

Affiliation: Department of Orthopedics, Trauma and Plastic Surgery, University

Hospital Leipzig, Liebigstraße 20, 04103 Leipzig, Germany
}

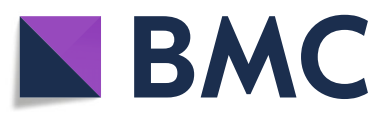

(c) The Author(s). 2021 Open Access This article is licensed under a Creative Commons Attribution 4.0 International License, which permits use, sharing, adaptation, distribution and reproduction in any medium or format, as long as you give appropriate credit to the original author(s) and the source, provide a link to the Creative Commons licence, and indicate if changes were made. The images or other third party material in this article are included in the article's Creative Commons licence, unless indicated otherwise in a credit line to the material. If material is not included in the article's Creative Commons licence and your intended use is not permitted by statutory regulation or exceeds the permitted use, you will need to obtain permission directly from the copyright holder. To view a copy of this licence, visit http://creativecommons.org/licenses/by/4.0/ The Creative Commons Public Domain Dedication waiver (http://creativecommons.org/publicdomain/zero/1.0/) applies to the data made available in this article, unless otherwise stated in a credit line to the data. 
(Continued from previous page)

Trial registration: $A Z 488 / 20$-ek

Keywords: Tibial plateau fracture, 3D imaging, 2D imaging, fluoroscopy, ORIF, Outcome, revision rate, infection

\section{Background}

Tibial plateau fractures constitute about $1 \%$ of all fractures occurring at an incidence of 10.3 per 100,000 annually [1-3]. Arthrosis rates of up to $44 \%$ and rates of revision operations of 25.3 to $45.0 \%$ have been described [4,5]. In addition to fracture severity, the reduction quality is crucial for the development of a posttraumatic arthrosis [6, 7]. For dislocated fractures, surgical therapy is the gold standard $[8,9]$. For intraoperative analysis of fracture reduction, conventional fluoroscopy is generally applied. Due to the convexity as well the flat lateral tibial plateau and the concave medial tibial plateau with respective different dorsal slopes, overlaps occur in the lateral fluoroscopy $[10,11]$. Complex fracture morphologies are difficult to assess and small joint steps cannot be assessed with sufficient certainty. Postoperative CT imaging is therefore recommended to verify the surgical outcome [12]. If there is a material malposition or an insufficient reduction of the articular surface, a revision operation is necessary. Intraoperative 3D imaging can provide additional information during the operation, which could prevent revision surgeries $[13,14]$. There are few studies that support its use in the treatment of intraarticular tibial plateau fractures. Thereby, intraoperative revision rates of up to $26.5 \%$ in the treatment of proximal tibial fractures are shown [15-18]. To the authors' knowledge, there is no study comparing the functional outcome after treatment of tibial plateau fractures using intraoperative 3D imaging versus conventional fluoroscopic evaluation using two planes (2D). The aim of this study was to determine whether the additional use of an intraoperative 3D imaging intensifier might help to improve the clinical outcome after surgical treatment of complex tibial plateau fractures. Secondary it was hypothesized, that the rate of postoperative revision surgeries can be reduced.

\section{Methods}

We performed a retrospective case control study at a level 1 trauma center. This study was conducted following approval from the local ethics committee and was performed in accordance with the principles of the Declaration of Helsinki. The consent to participate in the study was given by the patients.

All patients who were surgically treated for tibial plateau fractures were identified by querying the hospitals databases using the International Classification of Disease (ICD) code. We have formed two separate groups according to our predefined inclusion and exclusion criteria (Table 1).
Study group (3D): Patients who underwent open reduction and internal fixation between December 2015 and December 2018 using 2D and 3D imaging intensifier (Ziehm Vision RFD 3D, Fa. Ziehm Imaging, Nuernberg, Germany).

Control group (2D): Patients who were operated between 2005 and 2014 only by 2D fluoroscopy without 3D imaging.

We retrospectively evaluated the intraoperative revision rate, reasons for revision and operation time of both groups. Additionally, a minimum 12-month postoperative functional outcome was measured by using the KOOS and Lysholm Score [19-21]. Complications, postoperative revision surgeries and infections were analyzed.

Operation procedure: After fracture reduction, including reconstruction of the articular surface and placement of subchondral screws, 2D fluoroscopy was performed in the lateral and anterior- posterior plane. In contrast to the 2D group, an intraoperative 3D scan was now performed in the 3D study group. Whenever possible, as little osteosynthesis material as possible was placed close to the joint surface in order to keep possible artifacts to a minimum for the 3D scan. The decision for repositioning the screws and/or redo the reduction maneuver was made by the attending surgeon. Particularly intraoperative revision reasons were an intra-articular screw position or a joint step of more than $2 \mathrm{~mm}$.

In order to analyze the effect of intraoperative 3D imaging we compared the outcomes of the study group (3D group) to the historical collective (2D group).

We characterized our two groups by means of descriptive statistics: Mean \pm standard deviation (SD) for continuous and number (\%) for categorical variables.

Both groups were compared by a one to one matching of the patients. The matching criteria were age \pm 5 years, exact fracture classification by AO/OTA, gender and American Society of Anesthesiologists- Score (ASA). If no matching partner was found, the ASA score was changed by one unit $(n=4)$. If even then no suitable partner was found, gender $(n=1)$ or gender and ASA $(n=2)$ was adapted. During the matching process, attention was also paid to the follow-up time. The matching patient with the next possible follow-up time to the matching partner was selected. Further analyses were performed by using the Mann-Whitney-U test for non-parametric data (twotailed test, p- value < 0.05). The software SPSS (V.25, Fa. IBM, New York, USA) was used for the calculations and graphical presentations of the results. 
Table 1 Inclusion and exclusion criteria

\begin{tabular}{ll}
\hline Inclusion criteria & Exclusion criteria \\
\hline $\begin{array}{l}\text { Acute complex closed intraarticular } \\
\text { proximal tibial fracture Type B3, C1, } \\
\text { C2, C3 to AO/OTA [19] }\end{array}$ & $\begin{array}{l}\text { Open fractures } \\
\text { Fractures of type A, B1 and B2 } \\
\text { to AO/OTA }\end{array}$ \\
Age $\geq 18$ years & $\begin{array}{l}\text { Polytraumatized patients } \\
\text { (Injury Severity Score }>16)\end{array}$ \\
$\begin{array}{l}\text { Use of intraoperative 3D and 2D } \\
\text { imaging intensifier }\end{array}$ & Foreign residents \\
Follow-up $\geq 12$ months & Conservative treatment \\
Capable of consent & Pathologic fractures \\
\hline
\end{tabular}

\section{Results}

A total of 22 patients with AO/OTA B3 and C tibial plateau fracture were found according to our inclusion criteria. Four patients were excluded due to different circumstances: no follow-up could be determined for two patients, one patient died before the 1-year follow-up and one patient suffered a polytrauma. Finally, 18 patients were included in our 3D study group, of which 12 were women (Table 2). The mean age was $51.0 \pm 16.4$ years (range 23-85 years). We had 9x B3, 2x C1, 1x C2 and $6 \mathrm{x} \mathrm{C} 3$ fractures according to AO/OTA. The mean ASA score was $1.44 \pm 0.51$. The mean operation time was recorded with $128 \pm 46 \mathrm{~min}$. The mean follow-up time was $20.9 \pm 10.7$ months with the outcome scores shown in Table 3. Postoperative revisions had to be performed in $27.8 \%$ of cases. In one case a superficial wound revision was necessary due to a wound healing disorder, in one case we observed a deep surgical site infection with removal of the material and implantation of an unicondylar knee prothesis in the follow-up. One patient required a varus osteotomy due to posttraumatic valgus misalignment and one patient required a renewed reposition because of loss of reduction (Table 4).

Due to the 3D imaging an intraoperative new reduction or new placement of the implants had to be performed in $33.3 \%(6 / 18)$.

In one case, the intraoperative 3D imaging showed insufficient quality to adequately control the fracture reduction and implant positioning. All other 17 cases (94.4\%) showed good quality according to the surgical reports.

According to the matching criteria, 18 patients of the 2D control group could be matched in a ratio one to one (2D group: mean age: $50.3 \pm 15.2$ years; 11 females). Due to the matching both groups are comparable in terms of age, gender and ASA score $(p>0.05)$. The mean follow-up time of the 2D group was $55.5 \pm 34.7$ months $(p<0.001)$. The functional outcome scores of the 3D study and 2D control group are shown in Table 3. Especially the KOOS Sport/Rec sub score showed significantly higher results for the 3D group. The rate of postoperative revisions of the 2D group was $27.8 \%$. An infection has been observed in one case. The duration of the operations was $116 \pm 46 \min (\mathrm{p}=0.28)$.

If postoperative CT control imaging was performed in the $2 \mathrm{D}$ control group due to pain, one case showed intra-articular screw position and two cases showed joint steps $>2 \mathrm{~mm}$ without any operative revision. In the 3D study group no postoperative intraarticular implants or joint steps $>2 \mathrm{~mm}$ were detected.

\section{Discussion}

The hypothesis of the study that the additional use of intraoperative 3D imaging results in a relevant number of intraoperative revisions (33.0\%), potentially leading to a significantly improved outcome (KOOS Sport/Rec) could be approved. In the first analysis, this did not lead to a reduction in postoperative revisions. This might be due to the fact that in the 2D control group, relevant joint steps and suboptimal material position were tolerated in the presence of mild clinical symptoms (22.2\%).

The patients in both groups were about 50 years old and are comparable based on the matching process except for the duration of the follow-up time. Based on previous studies, the duration of follow-up should be evaluated subordinately, as previous studies could show that the outcome of the TPF is stable in the mediumterm period of up to ten years after trauma [22, 23].

The outcome between 3D group and 2D group are comparable with respect to Lysholm, KOOS Symptoms, KOOS Pain and KOOS ADL. The sub scores of KOOS Sport/Rec showed significantly better results in 3D group and a trend to higher KOOS Quality of Life scores ( $\mathrm{p}=$ 0.059). These subscales reflect complaints of the knee joint under higher loads, stress and more demanding movements. It is therefore conceivable that the optimized joint reduction after $3 \mathrm{D}$ imaging is not of high relevance for everyday activities and pain, but is particularly evident under physical stress. In the KOOS subscales for everyday movements, symptoms, and pain no significant differences could be shown between the both groups.

The majority of fractures in this study were severe joint injuries, $\mathrm{B} 3$ and $\mathrm{C} 3$ fractures according to $\mathrm{AO} /$ OTA. This explains lower scores compared to other studies [22, 24]. However, Jansen et al. who included patients with similar injury severity (C1-3 fractures according to AO/OTA) reported comparable results to our study (Lysholm 66.2; KOOS overall 67.8) [25]. Additionally, better results can be expected in patients with type $\mathrm{B} 1, \mathrm{~B} 2$, and $\mathrm{C} 1$ fractures compared to $\mathrm{B} 3$ and $\mathrm{C} 3$ fractures $[22,26,27]$.

A major advantage of this study should be not only to record the outcome of patients operated with 3D imaging in a minimum follow-up of 12 months, but also the comparison with patients operated without this technique. We decided to use matching as a method of 
Table 2 Comparison of 3D study group and matched 2D control group: Age, Gender, Trauma mechanism, ASA- Score, AO/OTA, Operation time, intraoperative Revision

\begin{tabular}{|c|c|c|c|c|c|c|c|c|}
\hline \multirow[t]{2}{*}{ Case } & \multirow[t]{2}{*}{ Age } & \multirow[t]{2}{*}{ Gender } & \multirow[t]{2}{*}{ Trauma mechanism } & \multirow{2}{*}{$\begin{array}{l}\text { AO/ } \\
\text { OTA }\end{array}$} & \multirow[t]{2}{*}{ ASA } & \multirow{2}{*}{$\begin{array}{l}\text { Operation } \\
\text { time (min) }\end{array}$} & \multicolumn{2}{|c|}{ Intraoperative Revision } \\
\hline & & & & & & & YES/ NO & Type of Revision \\
\hline 1 & 65 & $f$ & fall & C3 & 2 & 151 & YES & $\begin{array}{l}\text { Joint step }>2 \mathrm{~mm} \text {, } \\
\text { renewed reposition }\end{array}$ \\
\hline $\mathrm{m}_{1}$ & 60 & $f$ & fall & C3 & 2 & 121 & & \\
\hline 2 & 60 & $\mathrm{~m}$ & accident at work (machine) & C3 & 2 & 214 & NO & $\begin{array}{l}\text { Anterior fragment }<2 \mathrm{~mm} \text {, } \\
\text { no consequent }\end{array}$ \\
\hline $\mathrm{m}_{2}$ & 63 & $\mathrm{~m}$ & fall & C3 & 2 & 167 & & \\
\hline 3 & 43 & $\mathrm{~m}$ & motorcycle & C3 & 1 & 151 & NO & - \\
\hline$m_{3}$ & 42 & $\mathrm{~m}$ & accident at work & C3 & 1 & 142 & & \\
\hline 4 & 60 & $\mathrm{~m}$ & fall down stairs & B3 & 2 & 86 & NO & - \\
\hline $\mathrm{m}_{4}$ & 58 & $\mathrm{~m}$ & skiing & B3 & 2 & 115 & & \\
\hline 5 & 61 & $f$ & biking & $\mathrm{C} 1$ & 1 & 191 & NO & - \\
\hline$m_{5}$ & 56 & $\mathrm{~m}$ & biking & $\mathrm{C} 1$ & 1 & 111 & & \\
\hline 6 & 52 & $f$ & biking & B3 & 2 & 94 & NO & - \\
\hline$m_{6}$ & 47 & $f$ & biking & B3 & 2 & 71 & & \\
\hline 7 & 37 & $\mathrm{~m}$ & biking & C3 & 1 & 184 & YES & $\begin{array}{l}\text { Joint step }>2 \mathrm{~mm} \text {, cortical } \\
\text { bone chip, reposition }\end{array}$ \\
\hline $\mathrm{m}_{7}$ & 34 & $\mathrm{~m}$ & fall down from ladder & C3 & 1 & 243 & & \\
\hline 8 & 68 & $f$ & fall & C2 & 2 & 131 & YES & $\begin{array}{l}\text { Anterior joint step 3-4mm, } \\
\text { renewed reposition }\end{array}$ \\
\hline $\mathrm{m}_{8}$ & 66 & $f$ & fall & C2 & 2 & 77 & & \\
\hline 9 & 65 & $f$ & skiing & B3 & 2 & 64 & NO & - \\
\hline $\mathrm{m}_{9}$ & 70 & $f$ & fall & B3 & 2 & 86 & & \\
\hline 10 & 51 & $f$ & skiing & B3 & 1 & 47 & NO & - \\
\hline $\mathrm{m}_{10}$ & 54 & $f$ & fall & B3 & 2 & 119 & & \\
\hline 11 & 36 & $f$ & skiing & $\mathrm{C} 3$ & 1 & 132 & NO & - \\
\hline $\mathrm{m}_{11}$ & 37 & $\mathrm{~m}$ & biking & C3 & 2 & 135 & & \\
\hline 12 & 56 & $f$ & biking & B3 & 1 & 134 & YES & $\begin{array}{l}\text { Joint step }>2 \mathrm{~mm} \text { lateral, } \\
\text { renewed reposition, }\end{array}$ \\
\hline $\mathrm{m}_{12}$ & 54 & f & motorcycle & B3 & 2 & 76 & & \\
\hline 13 & 23 & $\mathrm{~m}$ & motorcycle & B3 & 2 & 155 & YES & $\begin{array}{l}\text { Negative dorsal slope, joint } \\
\text { step }>2 \mathrm{~mm} \text {, reposition }\end{array}$ \\
\hline$m_{13}$ & 27 & $\mathrm{~m}$ & fall & B3 & 1 & 141 & & \\
\hline 14 & 85 & $f$ & fall & B3 & 2 & 81 & NO & $\begin{array}{l}\text { Anterolateral joint step }<2 \mathrm{~mm} \text {, } \\
\text { no consequence }\end{array}$ \\
\hline $\mathrm{m}_{14}$ & 80 & $f$ & fall & B3 & 2 & 75 & & \\
\hline 15 & 38 & $f$ & biking & $\mathrm{C} 3$ & 1 & 95 & NO & - \\
\hline $\mathrm{m}_{15}$ & 43 & $f$ & biking & C3 & 2 & 104 & & \\
\hline 16 & 29 & $f$ & biking & B3 & 1 & 90 & NO & $\begin{array}{l}\text { Joint step }<2 \mathrm{~mm} \text {, } \\
\text { no consequence }\end{array}$ \\
\hline $\mathrm{m}_{16}$ & 33 & $f$ & fall & B3 & 1 & 77 & & \\
\hline 17 & 30 & $\mathrm{~m}$ & biking & $\mathrm{C} 1$ & 1 & 143 & NO & $\begin{array}{l}\text { Lateral joint step }<2 \mathrm{~mm} \text {, } \\
\text { no consequence }\end{array}$ \\
\hline $\mathrm{m}_{17}$ & 26 & $f$ & traffic accident & $\mathrm{Cl}$ & 2 & 170 & & \\
\hline 18 & 59 & $\mathrm{~F}$ & skiing & B3 & 1 & 159 & YES & Joint step $>2 \mathrm{~mm}$, renewed reposition \\
\hline $\mathrm{m}_{18}$ & 57 & f & biking & B3 & 1 & 63 & & \\
\hline
\end{tabular}


Table 3 Comparison of 3D study group and matched 2D control group: Follow UP time, Outcome parameters by Lysholm and KOOS sub scores, Postoperative revision

\begin{tabular}{|c|c|c|c|c|c|c|c|c|}
\hline Case & $\begin{array}{l}\text { Follow-up } \\
\text { (months) }\end{array}$ & Lysholm & Symptoms & Pain & $A D L$ & Sport/Rec & QOL & $\begin{array}{l}\text { Postoperative Revision/ } \\
\text { time after prim. surgery }\end{array}$ \\
\hline 1 & 40 & 99 & 96.4 & 97.2 & 100.0 & 85.0 & 100.0 & - \\
\hline$m_{1}$ & 42 & 99 & 85.7 & 94.4 & 97.1 & 55.0 & 75.0 & - \\
\hline 2 & 36 & 48 & 75.0 & 66.7 & 64.7 & 65.0 & 43.8 & $\begin{array}{l}\text { SSI, } 1 \text { month: spacer, } 6 \text { months: } \\
\text { unicondylar KTEP }\end{array}$ \\
\hline$m_{2}$ & 38 & 69 & 96.4 & 88.9 & 88.2 & 0.0 & 75.0 & $\begin{array}{l}\text { Screw intraarticular without } \\
\text { operative consequence }\end{array}$ \\
\hline 3 & 34 & 69 & 46.4 & 86.1 & 85.3 & 60.0 & 50.0 & - \\
\hline$m_{3}$ & 35 & 58 & 50.0 & 58.3 & 72.1 & 10.0 & 18.8 & $\begin{array}{l}14 \text { months: Arthrolysis and material } \\
\text { removal / intraop. screw } \\
\text { intraarticular }\end{array}$ \\
\hline 4 & 31 & 87 & 100.0 & 80.6 & 82.4 & 60.0 & 31.3 & - \\
\hline $\mathrm{m}_{4}$ & 31 & 86 & 100.0 & 80.6 & 97.1 & 90.0 & 62.5 & $\begin{array}{l}17 \text { months: Arthrolysis and } \\
\text { material removal }\end{array}$ \\
\hline 5 & 36 & 99 & 92.9 & 100.0 & 100.0 & 85.0 & 87.5 & $\begin{array}{l}5 \text { months: superficial wound } \\
\text { revision, } 19 \text { months: arthrolysis, } \\
\text { material removal }\end{array}$ \\
\hline $\mathrm{m}_{5}$ & 32 & 57 & 64.3 & 69.4 & 55.9 & 0.0 & 25.0 & $\begin{array}{l}17 \text { months: Arthrolysis and } \\
\text { material removal }\end{array}$ \\
\hline 6 & 32 & 37 & 57.1 & 52.8 & 64.7 & 25.0 & 31.3 & $\begin{array}{l}7 \text { months: arthrolysis, material } \\
\text { removal due to pain }\end{array}$ \\
\hline$m_{6}$ & 97 & 24 & 14.3 & 2.8 & 10.3 & 0.0 & 0.0 & $\begin{array}{l}15 \text { months: Arthrolysis and material } \\
\text { removal// intraop. joint } \\
\text { step }>2 \mathrm{~mm}\end{array}$ \\
\hline 7 & 25 & 34 & 39.3 & 33.3 & 41.2 & 15.0 & 18.8 & - \\
\hline $\mathrm{m}_{7}$ & 24 & 46 & 46.4 & 66.7 & 67.7 & 0.0 & 25.0 & $\begin{array}{l}13 \text { months: Arthrolysis and material } \\
\text { removal// intraop. joint step }>2 \mathrm{~mm}\end{array}$ \\
\hline 8 & 17 & 79 & 100.0 & 100.0 & 100.0 & 55.0 & 100.0 & - \\
\hline $\mathrm{m}_{8}$ & 133 & 33 & 64.3 & 58.3 & 60.3 & 0.0 & 18.3 & $\begin{array}{l}\text { Valgus gonarthrosis: after } \\
20 \text { months: Bicondylar KTEP }\end{array}$ \\
\hline 9 & 15 & 90 & 96.4 & 97.2 & 100.0 & 100.0 & 93.8 & - \\
\hline $\mathrm{m}_{9}$ & 25 & 73 & 96.4 & 75.0 & 86,8 & 0.0 & 31.3 & $\begin{array}{l}\text { Postop CT: screw too long } \\
\text { without operative consequence }\end{array}$ \\
\hline 10 & 15 & 71 & 71.4 & 97.2 & 98.5 & 80.0 & 43.8 & - \\
\hline $\mathrm{m}_{10}$ & 130 & 60 & 53.6 & 83.3 & 77.9 & 90.0 & 6.3 & $\begin{array}{l}\text { Eight times revision: osteomyelitis/ } \\
\text { infect; after } 20 \text { months } \\
\text { hemiprothesis }\end{array}$ \\
\hline 11 & 12 & 28 & 28.1 & 63.9 & 63.2 & 5.0 & 25.0 & $\begin{array}{l}\text { posttraumatic valgus } \\
\text { malalignment, varus osteotomy } \\
\text { after } 11 \text { months }\end{array}$ \\
\hline$m_{11}$ & 82 & 74 & 92.9 & 86.1 & 95.6 & 45.0 & 12.5 & posttraumatic valgus malalignment \\
\hline 12 & 12 & 36 & 50.0 & 61.1 & 77.9 & 0.0 & 31.3 & $\begin{array}{l}9 \text { months: valgus deformity, loss of } \\
\text { reduction-> reposition }\end{array}$ \\
\hline $\mathrm{m}_{12}$ & 39 & 31 & 28.6 & 36.1 & 42.7 & 20.0 & 31.3 & $\begin{array}{l}17 \text { months: Arthrolysis and material } \\
\text { removal (valgus deformity) }\end{array}$ \\
\hline 13 & 12 & 88 & 67.9 & 83.3 & 94.1 & 95.0 & 81.3 & - \\
\hline$m_{13}$ & 42 & 64 & 82.1 & 83.3 & 92.7 & 0.0 & 37.5 & - \\
\hline 14 & 12 & 95 & 100.0 & 100.0 & 95.6 & 95.0 & 100.0 & - \\
\hline $\mathrm{m}_{14}$ & 35 & 100 & 100.0 & 100.0 & 100.0 & 40.0 & 100.0 & - \\
\hline 15 & 12 & 62 & 71.4 & 63.9 & 66.2 & 45.0 & 62.5 & - \\
\hline
\end{tabular}


Table 3 Comparison of 3D study group and matched 2D control group: Follow UP time, Outcome parameters by Lysholm and KOOS sub scores, Postoperative revision (Continued)

\begin{tabular}{lllllllll}
\hline Case & $\begin{array}{l}\text { Follow-up } \\
\text { (months) }\end{array}$ & Lysholm & Symptoms & Pain & ADL & Sport/Rec & QOL & $\begin{array}{l}\text { Postoperative Revision/ } \\
\text { time after prim. surgery }\end{array}$ \\
\hline $\mathrm{m}_{15}$ & 37 & 69 & 78.6 & 86.1 & 98.5 & 25.0 & 37.5 & $\begin{array}{l}1 \text { month: loss of reposition/ } \\
\text { renewed reposition; } \\
20 \text { months: Arthrolysis and } \\
\text { material removal }\end{array}$ \\
& 12 & 89 & 89.3 & 97.2 & 97.1 & 95.0 & 100.0 & - \\
16 & 32 & 55 & 50.0 & 75.0 & 89.7 & 40.0 & 40.0 & $\begin{array}{l}21 \text { months: Arthrolysis and } \\
\text { material removal }\end{array}$ \\
$\mathrm{m}_{16}$ & 17 & 14.3 & 30.6 & 44.1 & 0 & 18.8 & - \\
17 & 12 & 74 & 92.9 & 83.3 & 91.2 & 65.0 & 43.8 & $\begin{array}{l}18 \text { months: Arthrolysis and } \\
\text { material removal }\end{array}$ \\
$\mathrm{m}_{17}$ & 77 & & & & & & & \\
18 & 12 & 79 & 60.7 & 77.8 & 85.3 & 50.0 & 50.0 & - \\
$\mathrm{m}_{18}$ & 69 & 44 & 60.7 & 63.9 & 88.2 & 0.0 & 50.0 & - \\
\hline
\end{tabular}

Symptoms KOOS Symptoms, Pain KOOS Pain, ADL KOOS Function in daily living, Sport/Rec KOOS Function in sport and recreation, QOL KOOS Quality of Life; SSI Surgical site infection, ${ }^{m}$ Matching partner from 2D control group; intraop. intraoperative

comparison, as only the image intensifier was modified throughout the course of time. For this, we had to accept the limitation of the longer follow-up of the control group, with the advantage of no further influencing factors.

Main matching criterion was the same fracture morphology (B1, B2, B3, C1, C2, C3) according to AO/ OTA, followed by the age \pm 5 years. These criteria were always met. In order to show the bone metabolism and the patient's state of health, the importance of gender and the ASA score followed.

The rate of intraoperative revisions due to the used 3D

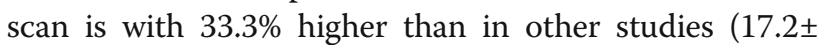
6.1\%; range 11.7- 26.5\% [14-18, 27]). The reasons for this are different revision criteria.

Based on the discussed parameters for joint gap with values between 1-4 $\mathrm{mm}$, we decided on a revision, if the joint gap is more than $2 \mathrm{~mm}[6,8,9,28-31]$. An intraarticular or overlong screw certainly causes symptoms. The most common fractures requiring intraoperative revision were $\mathrm{B} 3$ and $\mathrm{C} 3$ fractures (71.4 \%), which can be explained by the severely destroyed, multifragmentary articular surface and the split depression component.

For this 2D fluoroscopy has its limitations due to the concave anatomical joint conditions of the proximal tibia, with the result that joint steps $<5 \mathrm{~mm}$ cannot be adequately detected with fluoroscopy $[11,32,33]$. Conventional fluoroscopy is highly dependent on the set plane, while 3D imaging provides image information regardless of the position of the device [34, 35].

Due to the high rate of intraoperative revisions, our secondary hypothesis was that the rate of relevant postoperative revisions can be reduced by using 3D scan. Unfortunately, this cannot be confirmed. Both the study group and the control group show a postoperative revision rate of $27.8 \%$.
In further analysis of the 2D group, postoperative CT was performed in some patients. In two cases joint steps of more than $2 \mathrm{~mm}$, in one case an intraarticular screw and in one case a too long screw were detected but accepted without revision (22,2\%). The estimated number of unreported cases may be higher. The detected $4 \mathrm{pa}$ tients with revision criteria are the reason why there are no higher revision rates in the $2 \mathrm{D}$ group, but could probably be the reason for the poorer functional results of the 2D group in KOOS Sport/Rec and QOL.

There were no significant group differences between the $3 \mathrm{D}$ and 2D groups except the mentioned longer follow-up time of the control group. Nevertheless, a prolonged surgery time of approximately 12 minutes on average was observed for the study group, which was due to the use of intraoperative 3D imaging and performed intraoperative revisions in $33.3 \%$ of cases. Beisemann et al. also describe longer operation time by using intraoperative 3D scan (5 min) [16]. In recent years, numerous studies have been published on the use of intraoperative 3D imaging of joint injuries (proximal humerus, distal radius, proximal and distal tibia fractures). In most cases, acceptable image quality was shown for the assessment of an insufficient joint level or a material defect with high revision rates [15, 16, 36-39]. Overall, the technology of intraoperative 3D imaging remains reserved for the use of large clinics due to high acquisition costs.

\section{Limitations}

Due to the group comparison by matching according to the specific criteria, small differences in the ASA score (five cases), one for gender and one for both criteria together had to be tolerated. In this way a matching in the ratio one to one was possible between the groups. By softening the matching parameters, a matching ratio of 1:2 between the intervention group and the control 
Table 4 Parameters of interest for comparison of the 3D and 2D groups

\begin{tabular}{|c|c|c|c|}
\hline Parameter & 3D group & 2D group & $p$-Value \\
\hline Age & $51.0 \pm 16.4$ & $50.3 \pm 15.2$ & 0.82 \\
\hline Gender & $12 f: 6 m$ & $11 f: 7 m$ & 0.79 \\
\hline Fracture AO/OTA & $\begin{array}{l}9 \times B 3 \\
2 \times C 1,1 \times C 2,6 \times C 3\end{array}$ & $\begin{array}{l}9 \times \mathrm{B} 3 \\
2 \times \mathrm{C} 1,1 \times \mathrm{C} 2,6 \times \mathrm{C} 3\end{array}$ & 1.00 \\
\hline ASA & $1.44 \pm 0.51$ & $1.67 \pm 0.49$ & 0.27 \\
\hline Operation time (min) & $127.9 \pm 45.9$ & $116.3 \pm 45.7$ & 0.28 \\
\hline Follow - up (months) & $20.9 \pm 10.7$ & $55.5 \pm 34.7$ & $P<0.001$ \\
\hline Lysholm & $67.4 \pm 26.8$ & $62.0 \pm 21.4$ & 0.39 \\
\hline KOOS overall & $72.6 \pm 23.5$ & $65.8 \pm 21.6$ & 0.31 \\
\hline Symptoms & $69.8 \pm 26.6$ & $69.8 \pm 25.8$ & 0.94 \\
\hline Pain & $77.2 \pm 22.6$ & $71.8 \pm 23.0$ & 0.44 \\
\hline ADL & $81.1 \pm 19.5$ & $78.4 \pm 23.7$ & 0.70 \\
\hline Sport/Rec & $54.7 \pm 35.0$ & $26.7 \pm 31.6$ & $0.014^{*}$ \\
\hline QOL & $58.0 \pm 31.6$ & $38.2 \pm 26.1$ & 0.059 \\
\hline Intraoperative revision rate & $\begin{array}{l}33.3 \% \text { re-positioning of the screws } \\
\text { and/or re-reduction }\end{array}$ & Not registered & - \\
\hline Postoperative revision rate & $\begin{array}{l}27.8 \% \text { revision }(\mathrm{n}=5) \text { : } \\
\text { - wound revision } \\
\text { - SSI, spacer, unicondylar TEP } \\
\text { - varus osteotomy due to } \\
\text { valgus alignment } \\
\text { - renewed reposition } \\
\text { - early material removal }\end{array}$ & $\begin{array}{l}27.8 \% \text { revision }(n=5) \text { : } \\
-1 \times \text { screw intraarticular, material } \\
\text { removal } \\
\text { - } 2 \text { x loss of reposition/ renewed } \\
\text { reposition } \\
\text { - bicondylar KTEP } \\
\text { - SSI/ unicondylar KTEP }\end{array}$ & 1.00 \\
\hline $\begin{array}{l}\text { Postoperative revisions due to intraarticular } \\
\text { material position or joint step of } \geq 2 \mathrm{~mm}\end{array}$ & $\begin{array}{l}11.1 \%(n=2) \text { : } \\
\text { - varus osteotomy due to valgus } \\
\text { malalignment } \\
-1 \times \text { loss of reposition/ renewed reposition }\end{array}$ & $\begin{array}{l}22.2 \%(n=4) \text { : } \\
-1 \times \text { screw intraarticular, material } \\
\text { removal } \\
-2 x \text { loss of reposition/ renewed } \\
\text { reposition } \\
-1 \times \text { loss of reposition/ bicondylar } \\
\text { KTEP }\end{array}$ & 0.58 \\
\hline Material removal (months) & $\begin{array}{l}1 \mathrm{x} \text { arthrolysis and material removal } \\
\text { after } 19 \text { months }\end{array}$ & $\begin{array}{l}10 x \text { arthrolysis and material } \\
\text { removal } \\
\text { after } 16.9 \pm 2.6 \text { months }\end{array}$ & - \\
\hline Special details without revision & - & $\begin{array}{l}\text { 2xPostoperative recognized } \\
\text { joint step }>2 \mathrm{~mm} \\
\text { 1xpostoperative recognized } \\
\text { intraarticular screw } \\
\text { 1xpostoperative recognized } \\
\text { too long screw }\end{array}$ & - \\
\hline
\end{tabular}

SSI surgical site infection; Symptoms KOOS Symptoms; Pain KOOS Pain; ADL KOOS Function in daily living; Sport/Rec KOOS Function in sport and recreation; QOL KOOS Quality of Life; ASA American Society of Anesthesiologists- Score

* significant

group could certainly have been achieved. However, this was not desired. Also, the follow-up time varied between the $3 \mathrm{D}$ group and the 2D group. However, based on existing publications of the medium and longer followup time, the time of determination of the functional outcome should not have much influence, since it is below 5 years in both groups [22, 23]. Due to the retrospective study design, we had to rely on the data available in medical records (e.g. operation protocols). Unfortunately, not all intraoperative 3D scans were stored in the database, so that a later evaluation of the image quality of the 3D scan was not possible. It was necessary to rely on the documentation. Additionally, the 3D study group was compared with a historical control group. Nevertheless, the factors to be monitored, such as the implants, the surgical approach, general anesthesia and the postoperative physiotherapeutic regime (with $20 \mathrm{~kg}$ of partial weight-bearing for 6 weeks under free range of motion), did not change during this period. Tranexamic acid was not used in any of the groups. However, a certain selection bias that developed over time cannot be excluded with certainty. Due to the retrospective character, the decision for revision was made by the responsible surgeon. A possible learning curve in the supply of a 3D 
scan must remain suspected, which might hide additional advantages of the 3D scan. A further deficiency is that the patients of the study group and the control group were treated by different surgeons.

\section{Conclusion}

The intraoperative 3D imaging had in relevant number an immediately intraoperative consequence with revision. An influence of intraoperative 3D imaging on the midterm postoperative outcome could be shown in relation to better KOOS Sport/Rec.

\section{Abbreviations}

ASA: American Society of Anesthesiologists; AO/OTA: Arbeitsgemeinschaft Osteosynthese/Orthopaedic Trauma Association; CT: Computer tomography; KOOS: Knee Injury and Osteoarthritis Outcome Score; TPF: Tibial plateau fractures

\section{Acknowledgements}

None.

\section{Authors' contributions}

F.S. and R.H. were responsible for data control, study supervision, and writing of the manuscript. J.T., J.F. and P.H. performed the data interpretation. U.S. performed formal analysis, validation, and visualization of the study data, as well as further review and revision of the manuscript. P.H., U.S., and F.S. were responsible for the development of the study design, and project coordination. In addition, J.T. and J.F. undertook the manuscript review. All authors have critically revised the manuscript and agreed to the final version

\section{Funding}

No benefits or funding have been received or will be received from a commercial party, related directly or indirectly, to the subject of this article. Open Access funding enabled and organized by Projekt DEAL.

\section{Availability of data and materials}

The datasets used and/or analyzed during the current study are available from the corresponding author on reasonable request.

\section{Declarations}

\section{Ethics approval and consent to participate}

All procedures performed in human participants were in accordance with the ethical standards of the institutional research committee and with the 1964 Helsinki declaration and its later amendments. Informed consent was obtained from all individual participants included in the study. Ethical Committee at the Medical Faculty, Leipzig University:

Number of ethical approval: AZ 488 /20-ek

\section{Consent for publication}

Informed consent was obtained from all patients.

\section{Competing interests}

The authors declare no conflict of interest with respect to the research, authorship, and/or publication of this article.

Received: 19 January 2021 Accepted: 14 April 2021

Published online: 05 May 2021

\section{References}

1. Tscherne H, Lobenhoffer P. Tibial plateau fractures. Management and expected results. Clin Orthop Related Res. 1993:87-100.

2. Rademakers M, Kerkhoffs G, Sierevelt I, Raaymakers E, Marti R. Operative treatment of 109 tibial plateau fractures: five-to 27-year follow-up results. J Orthopaedic Trauma. 2007:21(1):5-10. https://doi.org/10.1097/BOT.0b013e31 $802 c 5 b 51$.
3. Elsoe R, Larsen P, Nielsen NPH, Swenne J, Rasmussen S, Ostgaard SE. Population-Based Epidemiology of Tibial Plateau Fractures. Orthopedics. 2015;38(9):e780-6. https://doi.org/10.3928/01477447-20150902-55.

4. Manidakis N, Dosani A, Dimitriou R, Stengel D, Matthews S, Giannoudis P. Tibial plateau fractures: functional outcome and incidence of osteoarthritis in 125 cases. International orthopaedics. 2010;34(4):565-70. https://doi.org/1 0.1007/s00264-009-0790-5

5. McNamara IR, Smith TO, Shepherd KL, Clark AB, Nielsen DM, Donell S, et al. Surgical fixation methods for tibial plateau fractures. Cochrane Database of Systematic Reviews [Internet]. John Wiley \& Sons, Ltd; 2015 [cited 2021 Mar 14]; Available from: https://www.cochranelibrary.com/cdsr/doi/10.1002/14 651858.CD009679.pub2/full

6. Singleton N, Sahakian V, Muir D. Outcome after tibial plateau fracture: how important is restoration of articular congruity? Journal of orthopaedic trauma. 2017;31(3):158-63. https://doi.org/10.1097/BOT.0000000000000762.

7. Wasserstein D, Henry P, Paterson JM, Kreder HJ, Jenkinson R. Risk of total knee arthroplasty after operatively treated tibial plateau fracture: a matchedpopulation-based cohort study. J Bone Joint Surg Am. 2014;96(2):144-50. https://doi.org/10.2106/JBJS.L.01691

8. Moore TM. Fracture--dislocation of the knee. Clin Orthop Related Res. 1981: $128-40$

9. Honkonen SE. Indications for surgical treatment of tibial condyle fractures. Clin Orthop Related Res. 1994:199-205.

10. Hashemi J, Chandrashekar N, Gill B, Beynnon BD, Slauterbeck JR, Schutt RC $\mathrm{Jr}$, et al. The geometry of the tibial plateau and its influence on the biomechanics of the tibiofemoral joint. The Journal of Bone and Joint Surgery American volume. 2008;90(12):2724-34. https://doi.org/10.2106/JBJS. G.01358.

11. Kotsianos D, Rock C, Wirth S, Linsenmaier U, Brandl R, Fischer T, et al. Detection of tibial condylar fractures using 3D imaging with a mobile image amplifier (Siemens ISO-C-3D): Comparison with plain films and spiral CT. Rofo. 2002;174(1):82-7. https://doi.org/10.1055/s-2002-19549.

12. Khoury A, Siewerdsen J, Whyne C, Daly M, Kreder H, Moseley D, et al. Intraoperative cone-beam CT for image-guided tibial plateau fracture reduction. Computer Aided Surgery. 2007;12(4):195-207. https://doi.org/1 0.3109/10929080701526872.

13. Rock C, Kotsianos D, Linsenmaier U, Fischer T, Brandl R, Vill F, et al. Studies on image quality, high contrast resolution and dose for the axial skeleton and limbs with a new, dedicated CT system (ISO-C-3 D). Rofo. 2002;174(02): 170-6. https://doi.org/10.1055/s-2002-20107.

14. Von Recum J, Wendl K, Vock B, Grützner P, Franke J. Intraoperative 3D Carm imaging. State of the art. Der Unfallchirurg. 2012;115:196.

15. Atesok K, Finkelstein J, Khoury A, Peyser A, Weil Y, Liebergall M, et al. The use of intraoperative three-dimensional imaging (ISO-C-3D) in fixation of intraarticular fractures. Injury. 2007;38(10):1163-9. https://doi.org/10.1016/j. injury.2007.06.014

16. Beisemann N, Keil H, Swartman B, Schnetzke M, Franke J, Grützner PA, et al. Intraoperative 3D imaging leads to substantial revision rate in management of tibial plateau fractures in 559 cases. Journal of orthopaedic surgery and research. 2019;14(1):236. https://doi.org/10.1186/s13018-019-1286-7.

17. Kendoff D, Citak M, Gardner MJ, Stübig T, Krettek C, Hüfner T. Intraoperative 3D imaging: value and consequences in 248 cases. J Trauma. 2009;66:232-8.

18. Kendoff D, Pearle A, Hüfner T, Citak M, Gösling $T$, Krettek C. First clinical results and consequences of intraoperative three-dimensional imaging at tibial plateau fractures. J Trauma. 2007;63(1):239-44. https://doi.org/10.1097/ TA.0b013e31804a8007.

19. Kessler S, Lang S, Puhl W, Stöve J. Der knee injury and osteoarthritis outcome score-ein funktionsfragebogen zur outcome-messung in der knieendoprothetik. Zeitschrift für Orthopädie und ihre Grenzgebiete. 2003; 141(03):277-82. https://doi.org/10.1055/s-2003-40083

20. Lysholm J, Gillquist J. Evaluation of knee ligament surgery results with special emphasis on use of a scoring scale. The American journal of sports medicine. 1982;10(3):150-4. https://doi.org/10.1177/036354658201000306.

21. Roos EM, Roos HP, Lohmander LS, Ekdahl C, Beynnon BD. Knee Injury and Osteoarthritis Outcome Score (KOOS) — development of a self-administered outcome measure. Journal of Orthopaedic \& Sports Physical Therapy. 1998; 28(2):88-96. https://doi.org/10.2519/jospt.1998.28.2.88.

22. Loibl M, Bäumlein M, Massen F, Gueorguiev B, Glaab R, Perren T, et al. Sports activity after surgical treatment of intra-articular tibial plateau fractures in skiers. The American journal of sports medicine. 2013:41(6): 1340-7. https://doi.org/10.1177/0363546513489524. 
23. Bäumlein M, Hanke A, Gueorguiev B, Nerlich M, Liodakis E, Perren T, et al. Long-term outcome after surgical treatment of intra-articular tibial plateau fractures in skiers. Archives of orthopaedic and trauma surgery. 2019;139(7): 951-9. https://doi.org/10.1007/s00402-019-03150-6.

24. Kraus TM, Martetschläger $F$, Müller $D$, Braun $K F$, Ahrens $P$, Siebenlist $S$, et al. Return to sports activity after tibial plateau fractures: 89 cases with minimum 24-month follow-up. The American journal of sports medicine. 2012;40(12):2845-52. https://doi.org/10.1177/0363546512462564.

25. Jansen H, Frey SP, Doht S, Fehske K, Meffert RH. Medium-term results after complex intra-articular fractures of the tibial plateau. Journal of Orthopaedic Science. 2013;18(4):569-77. https://doi.org/10.1007/s00776-013-0404-3.

26. Schatzker J, Mcbroom R, Bruce D. The tibial plateau fracture: the Toronto experience 1968-1975. Clin Orthop Related Res. 1979:94-104.

27. Waddell JP, Johnston D, Neidre A. Fractures of the tibial plateau: a review of ninety-five patients and comparison of treatment methods. J Trauma. 1981; 21(5):376-81. https://doi.org/10.1097/00005373-198105000-00007.

28. Buckley R, Tough S, McCormack R, Pate G, Leighton R, Petrie D, et al. Operative compared with nonoperative treatment of displaced intraarticular calcaneal fractures: a prospective, randomized, controlled multicenter trial. J Bone Joint Surg Am. 2002;84(10):1733-44. https://doi. org/10.2106/00004623-200210000-00001.

29. Giannoudis P, Tzioupis C, Papathanassopoulos A, Obakponovwe O, Roberts C. Articular step-off and risk of post-traumatic osteoarthritis. Evidence today. Injury. 2010;41(10):986-95. https://doi.org/10.1016/j.injury.2010.08.003.

30. Parkkinen M, Madanat R, Mustonen A, Koskinen S, Paavola M, Lindahl J. Factors predicting the development of early osteoarthritis following lateral tibial plateau fractures: mid-term clinical and radiographic outcomes of 73 operatively treated patients. Scandinavian J Surg. 2014;103(4):256-62. https://doi.org/10.1177/1457496914520854.

31. Thordarson DB, Motamed S, Hedman T, Ebramzadeh E, Bakshian S. The effect of fibular malreduction on contact pressures in an ankle fracture malunion model. J Bone Joint Surg Am. 1997;79(12):1809-15. https://doi. org/10.2106/00004623-199712000-00006.

32. Ebraheim N, Sabry FF, Mehalik JN. Intraoperative imaging of the tibial plafond fracture: a potential pitfall. Foot \& ankle international. 2000;21(1):6772. https://doi.org/10.1177/107110070002100112.

33. Gösling T, Klingler K, Geerling J, Shin H, Fehr M, Krettek C, et al. Improved intra-operative reduction control using a three-dimensional mobile image intensifier-a proximal tibia cadaver study. The Knee. 2009;16(1):58-63. https://doi.org/10.1016/j.knee.2008.07.012

34. Meulenkamp B, Martin R, Desy NM, Duffy P, Korley R, Puloski S, et al, Incidence, risk factors, and location of articular malreductions of the tibial plateau. Journal of orthopaedic trauma. 2017;31(3):146-50. https://doi.org/1 0.1097/BOT.00000000000000735.

35. Haller JM, O'Toole R, Graves M, Barei D, Gardner M, Kubiak E, et al. How much articular displacement can be detected using fluoroscopy for tibial plateau fractures? Injury. 2015;46(11):2243-7. https://doi.org/10.1016/j.injury.2 015.06.043.

36. Hammerle D, Osterhoff G, Allemann F, Werner CML. Comparison of intraoperative $2 D$ vs. $3 D$ imaging in open reduction and fixation of distal radius fractures. European Journal of Trauma and Emergency. Surgery. 2018:1-7.

37. Theopold J, Weihs K, Marquaß B, Josten C, Hepp P. Detection of primary screw perforation in locking plate osteosynthesis of proximal humerus fracture by intra-operative 3D fluoroscopy. Archives of orthopaedic and trauma surgery. 2017;137(11):1491-8. https://doi.org/10.1007/s00402-017-2 763-2.

38. Theopold J, Pieroh P, Henkelmann R, Osterhoff G, Hepp P. Real-time intraoperative 3D image intensifier-based navigation in reversed shoulder arthroplasty- analyses of image quality. BMC Musculoskelet Disord. 2019; 20(1):262. https://doi.org/10.1186/s12891-019-2657-2.

39. Hepp P, Theopold J, Jarvers J, Marquaß B, Josten C. Multiplanar reconstruction with mobile $3 \mathrm{D}$ image intensifier. Surgical treatment of proximal humerus fractures. Der Unfallchirurg. 2014;117(5):437-44. https:// doi.org/10.1007/s00113-013-2367-4.

\section{Publisher's Note}

Springer Nature remains neutral with regard to jurisdictional claims in published maps and institutional affiliations.

Ready to submit your research? Choose BMC and benefit from:

- fast, convenient online submission

- thorough peer review by experienced researchers in your field

- rapid publication on acceptance

- support for research data, including large and complex data types

- gold Open Access which fosters wider collaboration and increased citations

- maximum visibility for your research: over $100 \mathrm{M}$ website views per year

At BMC, research is always in progress.

Learn more biomedcentral.com/submissions 